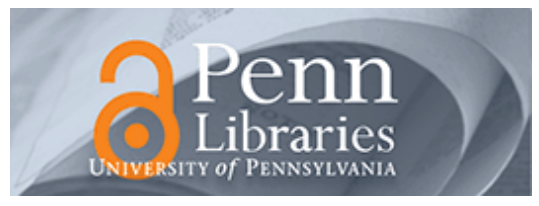

University of Pennsylvania ScholarlyCommons

September 2001

\title{
Redefining Government Roles In an Era of Standards-Based Reform
}

Margaret E. Goertz

University of Pennsylvania, Pegg@gse.upenn.edu

Follow this and additional works at: https://repository.upenn.edu/gse_pubs

\section{Recommended Citation}

Goertz, M. E. (2001). Redefining Government Roles In an Era of Standards-Based Reform. Retrieved from https://repository.upenn.edu/gse_pubs/7

Copyright Phi Delta Kappa International. Reprinted from Phi Delta Kappan, Volume 83, Issue 1, September 2001, pages 62-66. This material is posted here with permission of Phi Delta Kappa.

This paper is posted at ScholarlyCommons. https://repository.upenn.edu/gse_pubs/7

For more information, please contact repository@pobox.upenn.edu. 


\title{
Redefining Government Roles In an Era of Standards-Based Reform
}

\author{
Abstract \\ States and districts have embraced the goals of standards-based reform, but they have interpreted the \\ rather broad objectives in their own unique ways. Merely setting the mark may not be enough to ensure \\ adequate progress in our nation's schools, Ms. Goertz warns. \\ Comments \\ Copyright Phi Delta Kappa International. Reprinted from Phi Delta Kappan, Volume 83, Issue 1, September \\ 2001, pages 62-66. This material is posted here with permission of Phi Delta Kappa.
}




\title{
k0109goe.pdf
}

\section{Margaret E. Goertz, "Redefining Government Roles In an Era of Standards- Based Reform," Phi Delta Kappan, Vol. 83, No. 1, September 2001, pp. 62-66.}

\author{
Copyright Notice \\ Phi Delta Kappa International, Inc., holds copyright to this article, which may be \\ reproduced or otherwise used only in accordance with U.S. law governing fair \\ use. MULTIPLE copies, in print and electronic formats, may not be made or \\ distributed without express permission from Phi Delta Kappa International, Inc. \\ All rights reserved. Please fax permission requests to the attention of KAPPAN \\ Permissions Editor at 812/339-0018 or e-mail permission requests to \\ kappan@pdkintl.org.
}


A KAPPAN SPECIAL SECTION ON SCHOOL REFORM

\section{Redefining Government Roles In an Era of Standards-Based Reform}

\section{States and districts have embraced the goals of}

standards-based reform, but they have interpreted the rather broad objectives in their own unique ways. Merely setting the mark may not be enough to ensure adequate progress in our nation's schools, Ms. Goertz warns.

BY MARGARET E. GOERTZ

N 1990 President Bush and the country's governors adopted six ambitious national education goals to provide a common direction for educational improvement in all states. This action marked a turning point in the focus of federal and state education policy. Emphasis shifted from educational inputs to educational outcomes and from procedural accountability to educational accountability. Equity was reconceptualized as ensuring all students access to a high-quality educational program rather than providing supplemental and often compensatory services.

The roles of federal, state, and local governments in designing and implementing education reforms were expected to change as well. States would establish challenging content and performance standards for all students and provide support to schools,

MARGARET E. GOERTZ is co-director of the Consortium for Policy Research in Education, Graduate School of Education, University of Pennsylvania, Philadelphia. 
which would have more flexibility to design appropriate curriculum and instructional programs. The federal government and the states would align their education policies both vertically (federal to state) and horizontally (across programs within the U.S. Department of Education and across policies within states) to provide coherent policy guidance and instructional support.

This article uses data from a multistate, multidistrict study of education reform conducted by the Consortium for Policy Research in Education (CPRE) to examine the roles of federal, state, and local governments in standards-based reform and how intergovernmental relationships have influenced education reform policies and practice. ${ }^{1}$

\section{STRONG SIGNALS, WEAK GUIDANCE}

Since the mid-1990s, education policy at both the federal and state levels has sent strong and consistent signals about the goals of standards-based reform: 1) high academic standards, 2) accountability for student outcomes, 3) the inclusion of all students in reform initiatives, and 4) flexibility to foster instructional change. The provisions of Title I of the Improving America's Schools Act of 1994, for example, require states to establish challenging content and performance standards at least in reading and mathematics, to implement assessments that measure students' performance against these standards, to hold schools and school systems accountable for the achievement of all students, and to align their Title I programs with these state policies. The federal Individuals with Disabilities Education Act (IDEA) requires states to include students with disabilities in state and district assessment and accountability systems. Unlike earlier federal programs that circumvented state education policies because they did not encompass an equity agenda, these federal education policies were designed to support and be integrated with state and local reform initiatives.

States have generally embraced the broad objectives and architecture of standards-based reform, some in response to Title I and IDEA, many on their own. Forty-nine states have developed content standards in at least reading and mathematics, and 48 states have statewide assessments in these subjects. Thirty-three states have performance-based accountability systems that extend beyond public reporting of student test

\section{While setting the direction and creating an impetus}

for change, state and federal policies provided limited guidance about the substance of reforms.

scores. A growing number of states are including all students in their assessment, reporting, and accountability systems. ${ }^{2}$ In the CPRE study sites, state- and district-developed standards set expectations for student achievement and guided curriculum development, school improvement planning, assessments, and professional development at the local level. State and local accountability systems created incentives to improve schools and school systems by focusing attention on student outcomes and progress, by providing data for decision making, and by creating a press for more and better measures of student performance. ${ }^{3}$

While setting the direction and creating an impetus for change, these state and federal policies provided limited guidance about the substance of the reforms. In reaction to concerns about a national curriculum and the election of a more conservative Congress in 1994, the U.S. Department of Education chose to issue guidelines rather than regulations for Title I and to evaluate the process by which states developed their standards and assessments rather than the content or quality of these policies. Reviews have focused on issues of alignment and inclusion rather than rigor. ${ }^{4}$ Similarly, many states have developed standards documents that are fairly broad. This approach satisfied political and legal constraints that prohibited many states from mandating local curricula. Indeed, policy makers in some states felt they could not even advise local schools and districts about suitable curricula. Teachers and districts frequently complain, however, that state standards are too general to effectively guide local cur- 
riculum and instruction and that district and school staff members do not have the time or the expertise to translate these broad goals into practice. ${ }^{5}$ Kentucky is a case in point, where the state department of education has had to provide increasingly detailed instructional guidance in response to teachers' demands.

\section{GREATER FLEXIBILITY, MORE VARIABILITY}

Traditionally, the federal government has used targeting provisions, service mandates, and compliance audits to ensure that educationally disadvantaged students and other underserved populations receive access to federally funded programs and other services. Now, the government has aligned Title I with state standards-based reform policies so that incentives to provide a high-quality education to poor, low-achieving children have been embedded in these state performance and accountability systems. Because the states have been given the flexibility to define their own standards and design their own accountability systems, the success of the Title I program depends on the willingness of states and localities to en act policies that reflect federal objectives. Earlier research has shown, however, that granting more decision-making discretion to the states results in wider program and policy variations across the states. ${ }^{6}$ These variations can be undesirable if federal, state, and local priorities do not converge.

While state policies address the major objectives of the standards-based reform movement, they differ widely in their specifics: the scope and rigor of the standards they set for students, the goals they set for their schools, their measures of progress and success, and how they identify and support schools or districts in need of program improvement. These variations reflect differences in state demographics, political culture, educational governance structures and policies, and educational performance. In addition, although the intent of the federal legislation was to create single and "seamless" accountability systems that would treat all schools equally, only 22 states had single or "unitary" accountability systems in place in 2000-01.7 A congressionally mandated review panel concluded that the variability that results from flexibility in the Title I legislation "confound [s] efforts to target resources at lowperforming schools." achieving" in one state may be deemed successful in an- other state and therefore ineligible for assistance.

The flexibility/uniformity tradeoff extends to the local level as well. The more discretion states give their districts to create standards, set performance goals, or develop accountability policies, the greater the variation in local policy and practice. For example, in the states in our study that gave school districts the opportunity to design their own accountability systems, local policies ranged from highly centralized, sophisticated systems that held schools accountable for student performance on multiple measures to highly decentralized systems in which schools set goals and chose performance measures. These approaches reflected differences in district culture, leadership, and capacity. The two communities with highly refined district accountability systems viewed standards-based reform as a critical strategy for raising student performance and had spent several years developing systemic change strategies composed of standards and of assessments, accountability, and professional development aligned to district (and state) standards. The actions of the districts with the school-defined systems reflected both a strong tradition of decentralized management and a limited capacity to support or monitor school actions. In addition, accountability was not a central strategy for engendering reform.

\section{SCHOOL DISTRICTS STILL MATTER}

The school district's role in shaping and supporting standards-based reform is often overlooked in the current reform environment, which focuses on schools as the primary unit of change. Student performance data are now collected and reported at the school level, and states may intervene directly in the operation of low-performing schools regardless of how the district defines its responsibilities regarding school performance. Strong site-based decision-making laws, charter schools, and a push for school-selected whole-school reform programs also reflect a skepticism about the ability of districts to play a constructive role in instructional improvement.

But districts retain considerable authority and control over schools. In addition, they play a critical role in implementing state and federal policy and can choose to ignore, adopt, adapt, coordinate, or expand on government initiatives. As states strengthen their account- 
ability systems, it becomes more difficult for districts to ignore state (and aligned federal) policy. School districts, however, mediate between schools and state authorities, interpret state standards as they develop their own, and manage instructional reform. Districts are often the primary source of assistance to schools as they develop more effective curriculum and instruction. And their policies structure and channel schools' interactions with external agents and ideas.

The districts in the CPRE study used a mix of strategies to build the capacity of their staffs and schools, including aligning curriculum and instruction to state standards, building teacher knowledge and skills, using data to identify needs and select strategies for improvement, and targeting low-performing schools for assistance. ${ }^{9}$ Nearly all the districts took steps to align their curriculum and instruction, both vertically with state standards and horizontally with other elements of district and school policies and programs. But how districts deployed curricular and instructional change and how they sought to achieve alignment varied substantially. One difference was the degree to which districts sought to build alignment through changing curriculum, instruction, or both. Another was the choices districts made about whether and where to centralize curriculum and instruction. One study site, for example, developed lengthy and highly specific curriculum guides aligned to state standards. Curriculum revision was accompanied by staff development linked to the curriculum changes and school-based assistance for teachers as they made major changes in their instruction. Another district guided its language arts reforms primarily by aligning professional development to a set of principles and standards and did not adopt textbooks. A third district decided not to establish district-level standards or assessments in order to give schools greater flexibility and discretion over curriculum and instruction.

All the study districts provided some form of support for professional training as well. But once again, district strategies for building teachers' knowledge and skills varied along a number of dimensions. One difference was in the ways that districts facilitated teachers' pursuit of professional development. Another difference was the form of professional training and support, ranging from traditional menu-driven workshops to school-based support to building learning communities.

\section{PRACTICE MEDIATES POLICY}

At the end of the day, the success of standards-based
Nearly all districts took steps to align their curriculum and instruction with state standards. But how they deployed curricular and instructional change and sought to achieve alignment varied. teachers' practice and improved student achievement. Yet we know that teachers, as well as school districts, interpret policy through different lenses that reflect individual beliefs, knowledge, and practice..$^{10}$ The teachers in the CPRE study experienced and interpreted state and local reform policies in different ways. For some teachers, standards-based reform was just another in a long line of reform initiatives. For others, standards that were explicit in state frameworks or embedded in state assessments provided a catalyst and a language for thinking about their practice and student work. A few teachers felt that state policies impinged on the more innovative curriculum and assessment systems designed by their schools and districts. ${ }^{11}$

Across the states, however, teaching remained traditional, with most teachers balancing basics with opportunities to solve problems. Teachers wove selected innovative strategies, such as writers' workshops and manipulatives, into relatively stable practice. This approach reflected teachers' attempts to balance the press of state and local standards and assessments with what they saw as their students' particular needs. ${ }^{12}$ 


\section{CONCLUDING THOUGHTS}

In the past 10 years, standards-based reform has become the common focus of federal and state education policy. But, as the CPRE study shows, requiring standards-based reform and achieving it are two different things.

The normal tensions that have always existed, and $\underline{\text { Requiring standards-based }}$ reform and achieving it are two different things.

surely always will, between the federal, state, and local governments are at the heart of the variation in policy and practice we saw across states, districts, and schools. Although states and districts have embraced the goals of standards-based reform, they have interpreted the rather broad objectives in their own unique ways. Merely setting the mark may not be enough to ensure adequate progress in our nation's schools. If we are to achieve real improvement in student learning and achievement, policy makers must determine how much variability is acceptable and what the proper balance must be between compliance and flexibility.

1. CPRE conducted intensive case studies of education reform in 10 states, 23 school districts, and 56 schools between 1996 and 1999. The states - California, Colorado, Florida, Kentucky, Maryland, Michigan, Minnesota, Nebraska, Pennsylvania, and Texas — represent a range in the age, strength, and stability of state standards-based reform policies and, together, educate about $40 \%$ of U.S. public school students. The districts were selected for their activism in school improvement and standards-based reform but were demographically diverse. In spring 2000, CPRE researchers collected data on the assessment and account- ability policies of the other 40 states and updated information on the 10 case study states. Funding for this work was provided by the National Institute on Educational Governance, Finance, Policymaking, and Management of the U.S. Department of Education (Grant No. OERI-R308A60003), the Annie E. Casey Foundation, and the Pew Charitable Trusts, but the opinions expressed are the author's own.

2. Margaret E. Goertz and Mark Duffy, with Kerstin Carlson LeFloch, Assessment and Accountability Systems in the 50 States: 1999-2000 (Philadelphia: Consortium for Policy Research in Education, University of Pennsylvania, 2001).

3. Margaret E. Goertz, "Standards-Based Accountability: Horse Trade or Horse Whip?," in Susan H. Fuhrman, ed., From the Capitol to the Classroom: Standards-Based Reform in the States (Chicago: National Society for the Study of Education, University of Chicago Press, 2001), pp. 39-59; and Diane Massell, "The Theory and Practice of Using Data to Build Capacity: State and Local Strategies and Their Effects," in Fuhrman, pp. 148-69.

4. See Michael Cohen, "Memorandum to Chief State School Officers on Review of State Assessment Systems for Title I," 19 January 2001, available at www.ed.gov/offices/OESE/saa/.

5. Diane Massell, State Strategies for Building Local Capacity: Addressing the Needs of Standards-Based Reform (Philadelphia: Consortium for Policy Research in Education, University of Pennsylvania, CPRE Policy Brief No. RB-25, 1998).

6. See, for example, Mary T. Moore, Margaret E. Goertz, and Terry Hartle, "Interaction of Federal and State Programs," Education and Urban Society, vol. 15, 1983, pp. 452-78.

7. Goertz and Duffy, op. cit.

8. Independent Review Panel, Improving the Odds: A Report on Title I from the Independent Review Panel on Title I, January 2001, available at www.c-b-e.org.

9. Diane Massell, The District Role in Building Capacity: Four Strategies (Philadelphia: Consortium for Policy Research in Education, University of Pennsylvania, CPRE Policy Brief RB-32, September 2000).

10. See, for example, Educational Evaluation and Policy Analysis, vol. 12, 1990; William A. Firestone, David Mayrowetz, and Janet Fairman, "Performance-Based Assessment and Instructional Change: The Effects of Testing in Maine and Maryland," Educational Evaluation and Policy Analysis, vol. 20, 1998, pp. 95-113; James P. Spillane and Nancy E. Jennings, "Aligned Instructional Policy and Ambitious Pedagogy," Teachers College Record, vol. 98, 1997, pp. 449-81; and James P. Spillane and John S. Zeuli, "Reform and Teaching: Exploring Patterns of Practice in the Context of National and State Mathematics Reform," Educational Evaluation and Policy Analysis, vol. 21, 1999, pp. 1-27.

11. Suzanne M. Wilson and Robert E. Floden, "Hedging Bets: Standards-Based Reform in Classrooms," in Fuhrman, pp. 193-216.

12. Ibid. 